\title{
Emergent Religious Bodies and Noise Pollution: Perspectives on Enugu Metropolis and Environs
}

\author{
Obeagu Christian $\mathrm{C}^{*}$, Amaefule Eberechi $\mathrm{R}^{2}$ \\ ${ }^{1}$ Senior Lecturer, ${ }^{2}$ Faculty of Law, Department of Public Law, Enugu State University of Science and Technology, Enugu State, Nigeria
}

DOI: $10.36348 /$ sijlcj.2019.v02i09.002

| Received: 06.09.2019 | Accepted: 25.09.2019| Published: 28.09.2019

*Corresponding author: Obeagu Christian C

\section{Abstract}

Apart from such Othordox churches like Catholic, Anglican, Methodist, Apostolic and a few others, the presence of other religious bodies, especially of the Christian faith, is now ubiquitous and overwhelming within the Enugu metropolis and its environs. This ubiquity and, in some cases clustered, no doubt come with its attendant noise pollution in the environment to the detriment of the general public. This work examined the rising and emergent religious bodies in the Enugu urban centre and its adjacent environs, the impact of the cacophony of noise emanating from them which is harmful to the public in terms of decency and aesthetics as they are arbitrarily sited or located especially in purely residential zones. It made recommendations to the appropriate authorities on how to curb this menace and restore the lost glory and status of Enugu Metropolis as a clean city both in terms of neatness, serenity, structural and demographic aesthetics and decency.

Keywords: Enugu metropolis, religious bodies, noise pollution, environment.

\begin{abstract}
Copyright @ 2019: This is an open-access article distributed under the terms of the Creative Commons Attribution license which permits unrestricted use, distribution, and reproduction in any medium for non-commercial use (NonCommercial, or CC-BY-NC) provided the original author and source are credited.
\end{abstract}

\section{INTRODUCTION}

The ubiquitous presence of emergent and emerging religious bodies within Enugu metropolis and its environs would naturally create a cacophony of noise from the seemingly competing religious organizations dotting the environment. This state of affairs is compounded by the chaotic and unpleasant location of these church groups especially as the vast majority of them are sited or domiciled in purely residential buildings, with some clustering a particular storey building or street.

The alarming nature of this trend in the various activities is that almost every church group has its sound system and loud speakers mounted outside the meeting arena, with many towering above to the sky for outreach result in production. It is indeed an unwitting competition among these emergent churches to outdo one another in being heard most from loudspeaker production perspective. The Consequential effects of such competitive activities is noise pollution within the immediate and extended vicinity to the annoyance and discomfort of the general public particularly those residing or passing by the points of production.

This paper therefore seeks to examine noise pollution, effects of noise pollution, and emergent religious bodies in Enugu metropolis as source of noise pollution, control measures, conclusion and recommendations.

\section{Noise Pollution and the Effects Thereof Noise Pollution}

The word noise is cognate with the Latin word nausea, which means disgust or discomfort. According to Longman Dictionary of Contemporary English, noise is a sound, especially one that is loud, unpleasant, or frightening $\left[{ }^{1}\right]$. It is a sound or sounds, especially when it is unwanted, unpleasant or loud $\left[{ }^{1}\right]$. Noise pollution, also known as environmental noise or sound pollution is regular exposure to elevated sound levels that may lead to adverse effects on humans or other living organisms $\left[{ }^{2}\right]$. Noise pollution is thus the generation or propagation of noise in a given area which has detrimental effects on both humans and animals alike.

\footnotetext{
${ }^{1} \mathrm{https} / / / \mathrm{www}$.idoceonline.com $>$ dictionary accessed June 15, 2019 2:10pm

${ }^{1}$ Cambridge English Dictionary https://dictionary. Cambridge.org accessed June 15, 2019 2:15pm

${ }^{2}$ Copyright $(2017$ WWW. environmental pollution center.org accessed June 15, 2019 2:40pm
} 
Noise pollution in our contemporary society worldwide has remained a topical environmental issue on how to balance human activities and human comfort. This is particularly so in urban centres. As a result, not a few countries have taken drastic measures towards checkmating and controlling activities prone to noise pollution. Such actions often arise from people's complaints or responses from enquiries by relevant health or environmental authorities.

In United Kingdom, figures compiled based on the responses from local authorities to a Freedom of Information Act (FOI), reveals in the period (20082009), UK Council received 315, 838 complaints about noise pollution from private residences. This resulted in environmental health workers across the UK serving 8,068 noise abatement notices. In at least 12 months, 524 confiscations of equipment were authorized involving the removal of powerful speakers, stereos and televisions. In other cities such as Westminister City and London, they recorded an enormous numerical complaints and grievances about noise especially in residential areas $\left[{ }^{3}\right]$.

African countries in the A.U meeting in Addis Ababa in April 2010 unanimously agreed to practice what they call 'Quieter Environmental Healthy Living' in all member countries in order to improve standard of living for their people $\left[{ }^{4}\right]$.

Noise pollution has become a critical problem confronting city authorities in Nigeria today and Enugu metropolis is not an exception. Apart from such sources as factories, industries, business centres, motor parks, traffic jams, emergent religious organizations appear to be in the lead with respect to Enugu city on daily occurrence. This, unarguably has posed serious environmental challenge to the public.

Currently, in Enugu metropolis and its environs, it is an indubitable fact to assert that the emergence and erection of buildings, including makeshifts, for religious purposes, and most fearfully conversion of purely residential zones and buildings in this regard is quite alarming. This makes the need and management or curtailment of noise pollution constantly generated by these religious bodies quite imperative. Both the executive and legislative arms of

\footnotetext{
${ }^{3}$ C.B Chinedum 'Proliferation of Religious Bodies and Noise Pollution: Enugu as a Case Study’ (Unpublished LL.B

project submitted to Faculty of Law, Enugu State University of Science and Technology (ESUT), Enugu, June, 2017) P.2

https://WWW.whatdotheyknow.com/request/noisenuisance-complaints-in-the\#outgoing; accessed $3{ }^{\text {rd }}$ May, 2017.

${ }^{4}$ Ibid.https://www.amssa.net/actions/AU Addis Ababa April 2010.aspx accessed $3^{\text {rd }}$ May, 2017.
}

Enugu State government must rise to the occasion to redeem the fast-sliding glory of Enugu metropolis as a decent city.

\section{Effects of Noise Pollution in Society (Urban Centre) \\ Noise Pollution has some negative impacts in} Society which include the following:

\section{Interruption of Communication}

Noise pollution has a direct disruptive effect on conversation or communication going on within the vicinity of production. Those discussing would have to strain their voices and shout in order to achieve effective communication. This could be quite inconveniencing and may lead to total breakdown in communication.

\section{Disturbance of sleep}

Sleep is one of nature's balm to humanity after some hectic hours of work or other physical exertion. However, whether by the day or night one who is about to sleep or is already asleep will be disturbed and inconvenienced as soon as noise is produced especially when sustained over a time. This leads to mood changes and may have some other health effects on the individual concerned. In Abiola vs Ijeoma [ $\left.{ }^{5}\right]$, the defendant introduced poultry farming in a purely residential zone occasioning noise from the birds in the early morning hours coupled with foul odour emanating from it and thus interfered with the plaintiff's sleep. On the suit of the plaintiff, the court granted abatement to such nuisance forthwith.

\section{Impediments to Work}

Elevated noise pollution in no doubt would disrupt execution of certain work schedules and lead to loss of man hours as well as income. This is moreso when the nature of the work requires mental concentration and thinking. This was the situation in Tebite $v$ Nigerian Marine \& Training Coy Ltd $\left[{ }^{6}\right]$. The plaintiff, a legal practitioner, complained of the noise, smell and smoke produced by the defendant while carrying on the business of boat building and repairing as interfering with the preparation of his cases in his law chambers. The court found on evidence that the area, though a mix zone for commercial and residential purposes, nevertheless found that the noise and smell generated by the defendant's activity amounted to substantial interference with the plaintiff's comfort and convenience and ordered abatement by injunctive order to restrain the defendant as well as award of damages.

\section{Impedes Effective Learning}

Loud noise and sounds equally disrupt learning process. It hampers wholesome concentration by students just as it destabilizes the teacher from effective delivery and thus constitutes serious environmental

\footnotetext{
${ }^{5}$ [1979] 2 All NLR 268

6 [1971] 1 UILR 432
} 
malaise. The case of Christie $v$ Devies $\left[{ }^{7}\right]$ is quite illustrative. Here, a deliberate making of loud noises and shrieks so as to disturb music teacher's lessons was held to have amounted to noise as it disrupted the said lesson. The court declared such conduct as a nuisance and ordered abatement.

\section{Hearing Loss}

Hearing impairment is one of the direct consequences of environmental noise. This arises when a person is exposed to elevated noise for up to eight hours either at work place or in the neighbourhood. As noted by an environmentalist:

Repeated exposure to noise may result in temporary or permanent shifting of the hearing threshold of a person depending upon the level and duration of exposure. The immediate and acute effect of noise pollution is impairment of hearing (i.e total deafness). Human ears have sensory cells for hearing. If these cells are subjected to repeated sounds of high intensity before they have an opportunity to recover fully, they can become permanently damaged leading to impairment of hearing. Besides the sensory cells, the delicate tympanic membrane or the ear drum can also be permanently damaged by a sudden loud noise such as an explosion $\left[{ }^{8}\right]$.

\section{Emergent Religious Bodies in Enugu Metropolis as Source of Noise Pollution [ $\left.{ }^{9}\right]$}

Diverse human activities are carried out daily in Enugu City centre including religious bodies undertaking one programme or the other. These churches are in hundreds scattered all over the place including heavily populated residential zones and buildings as well as in the streets. The vast majority have powerful public address systems that produce piercing and deafening sound both within and outside the church auditorium. For long distance effect, horn speakers are mounted outside, in most cases on top of the roof that would set the stage for discordant and cacophonous output.

The Immediate neighbourhood and, indeed, the public must put up with this not just on Sundays but on daily basis as most of these churches engage in 'night vigil' and 'morning devotion' every now and then. While the former commences about 10p.m till dawn; the latter at about 5.a.m. when residents, in both cases, should be enjoying sleep.

\footnotetext{
${ }^{7}$ [1873] 1 Ch. 316

${ }^{8}$ Suresh K. Dhameja Society and Environment (Nai Sarak, Delhi: Sanjeev Kumar kataria, 2009) 322

${ }^{9}$ According to the last National population Census conducted in 2006, Enugu metropolis was credited with the figure of 722,664 with an estimation of 1.2 million people by 2012. See www.nigeriamasterweb.com/Nigeria06census.html accessed May 3, 2017
}

Examination of Affected Areas within Enugu Urban Garikki Awkunanaw Area (Densely populated) Ebony Paint Road

Garikki area of Enugu metropolis, an intense transportation hub, is a thickly populated residential area with moderate commercial activities. The presence of these discordant blaring noises drastically transformed that area as a noisy zone among Enugu residents generally. Ebony paint road is the worst hit with this cluster of churches in pure residential buildings fully occupied by tenants. A few specific cases will be relevant here:

- No. 366 Agbani Road, Garikki by Ebony Junction

An imposing three-storey building with three bedroom blocks/flats has the following religious ministries occupying it -

I. Omega Power Ministries (OPM) occupying the first floor.

II. Full Gospel Business Men's Fellowship International which occupies a flat on the second floor.

III. Real Power Gospel Ministry International is the occupant of a block on the third floor.

IV. Armour of Grace International Church is a joint occupant of the third floor. It is pertinent to point out that the Rivers State Transport Company (RSTC) occupies the ground floor with its own chaotic noise pollution.

- Soul Winners Assembly Church International is situate at No. 10 Ebony paint road, and occupies a flat in a purely residential building.

- No.11 Ebony paint road is occupied by Eckankar, a religious group is located is residential building without parking space. It is interesting to note that both the Soul-Winners Assembly Church International and Eckankar are closely located in the street with their respective loud speakers mounted outside their worship venues.

- No. 19 Ebony Paint road has Deuel Ministries Living Stone Global Gospel Centre in occupation.

- No. 20 of this street is occupied by the Lord's Chosen Charismatic Revival Movement (TLCCRM).

- $\quad$ Redeemed Christian Church of God (RCCG) is the occupier of No. 22 Ebony Paint road, Gariki Enugu.

- No. 45 Ebony Paint road is the location of the Glory House church in a residential building ostensibly meant for students. With the consequential noise being generated by this church, the students will be the worse off as conducive academic atmosphere is lost.

Each of these churches has its loud speakers mounted outside the meeting venue with specific 
activities distributed among the days of the week including 'morning devotion' 'night vigils/tarry night' and 'Bible Study'. Except the Full Gospel Businesses Men's Fellowship International that meets only on Thursday by $5.00 \mathrm{pm}$, recurring days of meetings by these churches cut virtually across the days of the week and could be ranked as follow in terms of regularity: Sunday $-100 \%$ as no church would not meet that day, Wednesday $-90 \%$, Friday $-75 \%$, Monday $-70 \%$, Tuesday $-55 \%$, Thursday $-40 \%$ and Saturday $-30 \%$.

\section{New Haven Area (Highbrow sparsely populated environment)}

New Haven area is one of the admirable residential zones in Enugu urban reputed for the serenity and decency. However, the peace and tranquility of this area has been radically abused and distorted by these religious activities. Assemblies of God church and Triumphant church of God operate in Umuezebi street of this area.

\section{Abakpa Nike Area (The most populated area in Enugu urban)}

Abakpa Nike is traditionally a slum area for low and middle income earners and that account for its densely population, but fastly transforming into a blossoming suburban area in Enugu metropolitan configuration.

At the Housing Estate area are the Seventh Day Adventist; and Divine Grace Assembly operating. The later conducts "night vigil" every Friday.

Operating at the Upper Housing Estate, Abakpa Nike include the following ministries: The Lord's Chosen Charismatic Revival Movement; The Sabbath Church of God; Cherubim and Seraphim Church: Church of Christ; Catholic Church (Seat of Wisdom); New Jerusalem: Glory of God Church all in clusters except a Methodist Church sited at the extreme of the street in the area.

At the Ogwuagor axis of this area, which is indeed, the soul of Abakpa Nike are inclusive of the under-mentioned churches/ministries; Assemblies of God Church; Miracle of God Mission Church International Inc; Four Square Gospel Church: Deeper Life Bible Church; The Lord's Chosen Charismatic Revival Movement; Mountain of Fire and Miracles Mission; Pillar Believers Evangelical church; Covenant People's Scripture International Ministry: Divine Chosen Vine Ministries International, Our Redeemer Anglican Church: Redeemed Christian Church of God: Dominion Church of God: Rock Family Church, and Queen of the Holy Rosary Catholic Church.

A good number of churches operate almost concurrently and indulge in "night vigil" raising the cacophony of noise production within the neighbourhood as the list is dominated by the so-called "Pentecostals".

\section{Measures to control Noise Pollution}

Attempts at controlling this noise pollution could be pursued from, at least, two angles administrative and judicial.

\section{Administrative Actions \\ Immediate Enforcement of Zoning Policy}

Environmental and planning officials should as a matter of urgency begin to enforce compliance with the existing zoning approach of the Enugu metropolis to checkmate these offending activities in relation to environmental sanity and aesthetics. This can be done by forcing such errant churches to vacate purely residential areas forthwith, and as well by not allowing emerging groups to spring up.

\section{Enlightenment Campaign}

Members of the public should be enlightened about the illegality of such religious activities by reason of location in exclusively residential zones. This could be done through radio jingles and television broadcast; by informing the public the need to report such activities to the appropriate government authorities, especially by those being offended by such conducts.

\section{Setting up Taskforce Team}

Enugu State Ministry of Environment should set up Taskforce Monitoring Group (TMG) using noise meter to enforce permissible noise levels across Enugu urban area with a threat of permanent closure if the group subsequently contravened the permissible noise limit. Thus, constant monitoring by a taskforce in enforcing the limit will assist in curbing the menace.

\section{Physical Sealing and Closure}

Where any religious group disregards warnings from the appropriate government agencies and continue to emit environmental noise in the neighbourhood, drastic measure of physical shutting down of such a centre should be the last administrative action. In accordance with the old maxim-desperate malady requires desperate remedy, the act of closing the venue and sealing it up would eventually bring such activities to end. There should be no sentiment about this. It has been applied in Lagos State and it worked and still working there. According to a source, on the $29^{\text {th }}$ day of June 2016, the Lagos State Government shutdown 70 Churches, 20 Mosques and about 11 hotels, club houses and beer parlours in a move aimed at reducing noise in the state ${ }^{10}$. The General Manager, Lagos State Environmental Protection Agency (LASEPA), Bola Shabi, who made this known, said that henceforth, the state government would no longer allow

\footnotetext{
${ }^{10}$ Monsuru Olowoopejo, 'Lagos shuts down 70

Churches, 20 Mosques over noise pollution', Vanguard Newspaper, June 30, 2016, p.3
} 
make-shift buildings to be used as places of worship. In his words:

Precisely about 70 Churches, 20 Mosques and about 11 hotels, club houses and beer parlours were shut and we have given them some directives to follow. We have been so strict now that we are not going to even allow make-shift churches in the state any longer. What I mean by make-shift, using tents and uncompleted building, we are not going to allow that any further in the state ${ }^{11}$.

\section{The exercise yielded the desired positive result as Shabi enthused}

But I will strongly tell you that the level of compliance is more on the Mosque area, because immediately you shut them, they instantly bring down their speakers or reduce the noise they make ... As at today, we are only able to reduce the noise level to about 35 percent. That is not a pass mark yet. So, until we reach that target of 70 to 80 per cent, we will continue the enforcement. Enforcement is a continuous exercise and we have set a target for ourselves. We want to ensure that Lagos is noise-free by the year 2020. With our status as a mega city, by the year 2020 we will be free of noise $\left[{ }^{12}\right]$.

Administrative action of closure of the offending church is also used by the Enugu State Ministry of Environment officials in tackling this issue. An illustrative case was a petition filed at the ministry by a resident of No.24 Ozobu Street, Idaw River Layout, Enugu on the $16^{\text {th }}$ of August, 2016, against Time Mission Church for "incessant noise pollution emission and nuisance".

\section{The Petition Read Thus}

That the church is situated in the midst of residential homes in a quiet residential area but unfortunately, the church has resorted to polluting the environment and breaching the peace enjoyed by the residents of this area by mounting a horn-speaker at the top of the roof of the church that produces terrible noise $\left[{ }^{13}\right]$.

Consequent upon this petition, the ministry dispatched some officials to the location for the purpose
11 Ibid.
12 Ibid.
${ }^{13}$ C.B Chinedum Op. cit. at 37. Another petition was filed on the $18^{\text {th }}$ September, 2015 by the Landlord of No 21 Igboeze Street, Independence Layout, Enugu, to the Ministry of Enugu for the environmental pollution generated by church of Elijah situated adjacent the building. The noise emanated from the church made tenants to demand for refund of the rents paid on the property, owing to the inhabitable state of the place caused by the noise. The ministry intervened which resulted in the closure of the offending church. of investigating the complaint armed with noise meter (to measure the level of noise emanating therefore) during the church service. The church was subsequently foreclosed as a result, and thus restoring sanity and order in the street.

\section{Demolition of illegal and substandard building worship centres}

Worship centres that not only generate noise pollution but are themselves illegal and substandard in quality thus, constituting danger to lives and property should be promptly demolished by the planning authority in the state after appropriate notices to the owners failed to yield the expected results. This should serve as a bitter pill to such persons and as deterrence to others in due course.

The cumulative effect of this measure is geared towards enhancing appropriate and effective physical developments and aesthetic beauty of the environment, as much as bringing about an atmosphere of serenity and tranquility with which Enugu metropolis from time immemorial is known for. Again, Lagos State had, perhaps, led the way in taking the bull by the horn in these drastic but necessary measures. In this regard, a source revealed that:

For failing to comply to (sic) the state's sanitation law, the Lagos State Government has demolished no fewer than 590 structures to ensure strict adherence by residents. This development was contained in the document obtained by Vanguard and signed by the Commissioner for Environment, Mr. Tunji Bello, while briefing the press on the activities of its ministry in the last 365 days. The ministry through the sanitation service department issued 636 abatement notices to landlords and owners of the structures who defaulted; out of which 157 owners complied with the state government's directives. The document further revealed that during the year under review, 107 enforcement exercises were conducted across the state to attain a cleaner and sustainable environment, while 590 structures were separated (demolished) to comply with the state environmental law. It also stated that of the 530 houses inspected for compliance with the environmental laws, about 310 were unsatisfactory $\left[{ }^{14}\right]$.

\section{Judicial Process}

Where any or all of the above measures under administrative action fail, the appropriate authority would have to make the last resort to judicial remedy. This is to enable effective enforcement of the state laws since no one or group is above the law. In the same vein, law is made for man not man for law. In other words, law is made for advancement of human interest

\footnotetext{
14 Monsuru Olowoopejo 'Sanitation: Lagos demolishes 590 structures for non-compliance', Vanguard,

Tuesday, May 19, 2015, p.47
} 
in life not man using law or abusing law to the detriment of human society.

The judiciary organ is imbued with all the powers and authority to interpret and declare the law, and having so done with finality and binding. This is necessary where some bodies decide to be intransigent and recalcitrant with respect towards administrative orders and notices for remedial actions.

Enugu state can follow in the heels of both Lagos and Edo states in pursuing the legal option in appropriate circumstances.

First, in Lagos State, the police arrested six persons on the $10^{\text {th }}$ day of February, 2016 for allegedly disturbing the peace of residents of Olaomibiyi Street, Ogba during a church service. The membersNgozichukwu Onyebuchi (44), Clement Eromosele (26), Chukwudi Akwegbu (26), Chibuzor Chukwu (18), Godspower Enudi (21) and Okorie Livinus (36) - were arraigned in a Lagos Magistrate's Court sitting in Ogba $\left[{ }^{15}\right]$.

It was learnt that the landlord and the residents of the building where the defendants gathered to worship had complained that the congregation caused noise pollution whenever they prayed. They were said to have cautioned the worshippers to lower their voices, but the members reportedly declined. The church was reported to the police at the Pen Cinema Division, who arrested the six members on January 14 during Sunday service, while the others were said to be at large $\left[{ }^{16}\right]$.

They were brought before a Chief Magistrate, Mrs T. Akanni on two counts of engaging in a conduct capable of causing a breach of the peace. The Offence, according to a police prosecutor, Inspector Clifford Ogu, is punishable under sections 410 and 166 (1) (d) of the criminal law $\left[{ }^{17}\right]$. The charges consisted in first, conspiracy to commit felony to wit: conduct likely to cause a breach of the peace; and second, did unlawfully convert to residential apartment of the aforementioned house to a church and disturbed peace of the landlord and other tenants as they were praying on top of their voices.

The accused, however, pleaded not guilty to the charges and elected summary trial. The presiding Magistrate Akanni, admitted them to hail in the sum of $\$ 50,000$ each with two sureties each in like sum, and each surety must provide evidence of tax payments and the residential address to the court for perfection of the defendants bails. The case was then adjourned.

\footnotetext{
${ }^{15}$ Metro Plus, 'Church members arrested during service for noise pollution', Punch Newspaper, February 11, 2016, p. 35.

16 Ibid.

${ }^{17}$ Laws of Lagos State, Nigeria, 2011.
}

\section{Edo State Case}

Edo Sate government has also demonstrated big courage in prosecuting noise emitters in the society to checkmate the menace, and that with big success. According to the source,

Edo State Commissioner for Environment and sustainability, Reginald Okun, had disclosed that the State Government has secured the conviction of four persons for noise pollution. Okun, who disclosed this yesterday, during an interview with newsmen in Benin, Edo State capital said. 'The Government is clamping down on persons who violate laws on noise pollution in the state. We have secured four convictions with more persons to be charged to court soon' $\left[{ }^{18}\right]$.

Okun regretted that people disregard laws on noise pollution, noting that the government will not tolerate any behaviour that disregards law and order, or people being laws into themselves. He lamented that the greatest culprits were some religious centres, relaxation spots, night clubs and bars $\left[{ }^{19}\right]$.

Ministry of Environment of Enugu State Government should key into this judicial path that is working in both Lagos and Edo states in this regard. This is moreso when the author has not been able to lay hands on any successful prosecution of noise pollution case by a relevant environmental or planning authority in the State.

\section{CONCLUSION}

This research revealed abundant evidence showing a prevailing noise pollution from religious bodies within Enugu urban and its sub-urban areas as well as the associated implications and effects. Findings also revealed that there has been not much efforts in curbing this tortious act by judicial process except halfhearted administrative actions. This may result from perhaps, fear by state officials for being branded 'antiChrist' or 'being possessed' by the devil.

As a result, the existence and emergence of religious bodies in Enugu metropolis is ubiquitous and disquieting to conscientious residents of Enugu city and accordingly calls for intervention.

\section{RECOMMENDATIONS}

In order to arrest the above alarming noise dangers from the identified point source, the following recommendations are hereunder set forth:

\footnotetext{
18 'Noise Pollution: Edo Secures 4 convictions', Daily Sun, Tuesday, April 3, 2018,p.41

${ }^{19}$ Ibid. He said, 'They do all these without considering its advance effect on the immediate environment. The standard practice for use of speakers in such place, is that they set-up some form of sound-proof roof system to restrict the sound.'
} 
Enugu State Ministry of Environment officials must take steps to close down all religious bodies sharing accommodation with tenants in residential premises whether in storey buildings or normal bungalows. This is completely unhealthy as it constitutes serious environmental hazards. The incongruous and chaotic situation as obtained in the three-storey-building situated at Gariki, Enugu, housing three different religious bodies, Rivers State Transport Company (RSTC) vehicles and resident tenants is quite unhealthy, indecent and disorderly. It ought not to be so.

Environmental officers must enforce soundproof devices in all churches/ ministries having their own buildings but sited in clearly residential zones/areas. This is to avoid noise pollution within the neighbourhood with its associated health risk and dangers to the public.

The habitual mounting of strident loudspeakers either on top of worship buildings, poles reaching high heavens or directly in front of Church buildings must be stopped forthwith after due notices. Many of these churches are guilty of this practice as it is sort of competition among them, perhaps, ignorance of the health implications of their conduct to a largerly uninformed public on their right to quiet and decent environment.
Provision of affordable and separate area designated as 'religious zone' where religious bodies could put up their worship places. Of course, the multiplicity of these churches/ministries, which the great church of Christ Evangelist, Innocent Akpandu Nwigwe dubbed "Churchianity" rather than "Christianity" arose essentially on improper motives of seeing the church as money-making venture by many adherents of Christendom.

This situation is further emboldened by the Constitutional right of freedom of religion, conscience and to manifest it openly in public. In order to give vent to this Constitutional provision, available safe space should be provided where these bodies could be situated and worship services go unhindered in an ordered and lawful manner without endangering the health of the public at large as the present scenario presents.

Finally, all unlawful and shanty structures put in place for worship purpose should be demolished. This is not only to abate the present unhealthy practices but also to prevent likely deaths that may result from such defective structure falling unexpectedly. This is part of the environmental and planning law regulation of a modern state. More so, being used for religious worships for creating environmental noise, the appropriate environmental and planning officials must wield that big hammer in demolishing such structures for healthy, decency and aesthetic reasons. 